\title{
Forage and grain yields of dual-purpose triticale as influenced by the integrated use of Azotobacter chroococcum and mineral nitrogen fertilizer
}

\author{
Heba Sabry Attia Salama, ${ }^{1}$ Hala Hassan Badry ${ }^{2}$ \\ ${ }^{1}$ Crop Science Department; ${ }^{2}$ Soil and Water Science Department, Faculty of Agriculture, Alexandria \\ University, Alexandria, Egypt
}

\section{Highlights}

- Triticale is a promising dual-purpose crop that can be utilized for forage and grain production under irrigated Mediterranean conditions.

- Around 7.23 t ha ${ }^{-1}$ forage yield was obtained from the dual-purpose triticale with a slight decrease (19\% in average) in final grain yield.

- Dual-purpose production system was profitable due to the good prices of triticale green forage in the region.

- Azotobacter chroococcum seed inoculation allowed for the reduction of mineral nitrogen rate to 50\% without sacrificing the forage and grain yields.

- The integrated use of Azotobacter chroococcum seed inoculation with mineral nitrogen resulted in $43 \%$ decrease in fertilization costs.

\begin{abstract}
The utilization of dual-purpose cereals is encouraged in the Mediterranean environments to fill a feed gap during the winter season. Triticale is a promising dual-purpose crop for forage and grain production. Studies on the variations in productivity and quality of dual-purpose triticale under variable fertilization man-
\end{abstract}

Correspondence: Heba Sabry Attia Salama, Crop Science Department, Faculty of Agriculture, Alexandria University, Aflaton street, El Shatby, 21545Alexandria, Egypt.

Tel.: +201120902333

E-mail: heba.salama@alexu.edu.eg

Key words: Biofertilizer; forage yield; forage quality; grain yield; mineral nitrogen; Triticosecale Wittmack.

Contributions: HSAS, designing and carrying out the field experiments, performing the forage quality laboratory analysis, data collection and statistical analysis, searching for references and writing the manuscript; HHB, Azotobacter inoculum isolation and preparation, laboratory analysis, searching for references and revising the written manuscript.

Conflict of interests: the authors declare no potential conflict of interests.

Received for publication: 5 August 2020.

Revision received: 4 November 2020.

Accepted for publication: 18 November 2020.

${ }^{\circ}$ Copyright: the Author(s), 2021

Licensee PAGEPress, Italy

Italian Journal of Agronomy 2021; 16:1719

doi:10.4081/ija.2020.1719

This article is distributed under the terms of the Creative Commons Attribution Noncommercial License (by-nc 4.0) which permits any noncommercial use, distribution, and reproduction in any medium, provided the original author(s) and source are credited. agement are scarce. This study was carried out during winter 2018/2019 and 2019/2020, in Northern Egypt, to evaluate the performance of triticale grown in dual-purpose and grain-only production systems under variable mineral $\mathrm{N}(\mathrm{mN})$ rates (zero, 25, $50,75 \%$ of the recommended), accompanied with Azotobacter chroococcum (AC) seed inoculation, as well as $100 \% \mathrm{mN}$ application without AC. The application of $50 \% \mathrm{mN}$ with $\mathrm{AC}$ seed inoculation resulted in an average of 7.23, 7.27 $\mathrm{t} \mathrm{ha}^{-1}$, forage and grain yields, respectively. Moreover, forage and grain crude protein reached 125.57, and $200.60 \mathrm{~g} \mathrm{~kg}^{-1}$, respectively. Forage fibre fractions were non-significantly variable among the fertilizer treatments. A. chroococcum seed inoculation, thus, allowed for the reduction of the used amount of $\mathrm{mN}$ to $50 \%$ without sacrificing the forage and grain yields and protein content. In the dual-purpose system, an average of $7.23 \mathrm{t} \mathrm{ha}^{-1}$ forage yield was obtained with little reduction in the grain yield (19\% reduction in average). Meanwhile, grain crude protein content was higher in dual-purpose system $\left(201.38 \mathrm{~g} \mathrm{~kg}^{-1}\right)$ than in grain-only system $(182.98 \mathrm{~g}$ $\mathrm{kg}^{-1}$ ). In similar conditions to the current study, it is recommended to expand the production of dual-purpose triticale in the winter while reducing $\mathrm{mN}$ fertilizer rate to $50 \%$ in combination with $\mathrm{AC}$ seed inoculation.

\section{Introduction}

Sustainable agriculture encourages the integration of crop and livestock production systems, in order to make the maximum benefit out of the available agricultural inputs, especially in the developing countries suffering from increased populations and limited resources. However, one of the main challenges facing this mixed farming system is the exposure of livestock to seasonal feed gaps, especially in the winter. Thus, there is a pressing need to expand the utilization of dual-purpose winter cereals, as a successful strategy to fill the feed gap in the winter season (Bell et al., 2015). These are crops that are cut during the vegetative growth stage, early in the winter, and then left till maturity and grain production. This practice is highly encouraged, especially in the 
Mediterranean countries to narrow the gap between feed demand and supply (Sadreddine, 2016; Rajae et al., 2017; Salama, 2019).

Triticale (X Triticosecale Wittmack) is a hybrid crop species developed by crossing two cereal crops; i.e., wheat (Triticum spp.) and rye (Secale cereale L.). It combines the best of both crops, the nutritional value of wheat along with the hardiness and nutrientuse efficiency of rye (Ayalew et al., 2018). Thus, triticale became an alternative cereal crop, mainly grown for grain production, in environments suffering from nutrient deficiency, biotic and abiotic stresses (Blum, 2014; Liu et al., 2017). In 2018, triticale covered a global area of around 4 million hectares, with a total grain production of 13.5 million tons (FAOSTAT, 2018). Interest has been developed in utilization of triticale as forage since the $1970 \mathrm{~s}$ (Baron et al., 2015). When densely grown as forage, its large canopy permits high light interception and its abundant root system allows for better soil attachment and nutrient absorption (Ayalew et al., 2018). In addition, its good performance, even in less favourable environments, gives it a special advantage over other cool-season forages (Blum, 2014). Being a drought tolerant crop, it proved distinction particularly in semi-arid and arid environments of the developing countries (Bilgili et al., 2009). It was, thus, proposed as a replacement dual-purpose crop in regions where environmental conditions limit the productivity of rye, wheat, barley and oat (Baron et al., 2015; Giunta et al., 2015).

The success of a dual-purpose production system is greatly dependent on the applied agricultural practices, amongst is the fertilization management. Nitrogen $(\mathrm{N})$ fertilization is a key agricultural input, especially in poor, low-fertility soils. In a dual-purpose system, $\mathrm{N}$ availability plays a crucial role in determining the crop's regrowth ability after cutting (Hajighasemi et al., 2016). However, the continuous application of mineral $\mathrm{N}$ fertilizer, that is frequently lost in several forms, leads to its deficiency in the soil (Bilal et al., 2017), in addition to being a major cause of environmental pollution (Salama and Badry, 2020). Moreover, the increasing prices of the mineral fertilizers is adding an additional financial burden on the farming systems especially in the developing countries (Salama, 2019). Thus, the need to find more affordable, yet environmentally-friendly alternatives, is continuously increasing. Hence, the integration of biofertilizers, known for their nitrogen fixing potentials, with mineral $\mathrm{N}$ is a highly recommended practice to decrease the use of mineral fertilizers and, thus, limit their harmful environmental effects.

Azotobacter species are a group of free-living, non-symbiotic nitrogen fixing microbes, that reported a significant contribution to the yield improvement of cereals (Aazadi et al., 2014). The inoculation of oat with Azotobacter reduced the amount of mineral N from $120 \mathrm{~kg} \mathrm{ha}^{-1}$ to $80 \mathrm{~kg} \mathrm{ha}^{-1}$ (Bilal et al., 2017). In addition, Azotobacter, known as plant growth promoting rhizobacteria (PGPR), proved significant impact on plant growth and development through, occupying the rhizosphere and secreting growth promoting metabolites, increasing nutrient use efficiency and, ultimately boosting biological $\mathrm{N}$ fixation (Jnawali et al., 2015). Among the various Azotobacter species, Azotobacter chroococcum is known for its significant impact on crop production and soil fertility (Wani et al., 2016). It is, however, evident that the application of only bio-fertilizers does not give the maximum boost to crop productivity, and, thus, partial substitution of mineral fertilizer with bio-fertilizer is suggested to achieve the best results from the cropping system (Habiba et al., 2018). Studies evaluating the application of PGPB as seed inoculants have been mostly focused on genotypes exclusively recommended for grain production, with few researches on dual-purpose crops (Quatrin et al., 2019). In this regard, research results reported variations in the yield and quality of dual-purpose wheat, oat and sorghum (Bilal et al., 2017; Patel et al., 2018; Quatrin et al., 2019), inoculated with bio-inoculants according to the rate of applied $\mathrm{N}$ fertilizer. Meanwhile, studies on the variations in productivity and quality of dual-purpose triticale under variable integrated mineral- and bio-fertilization management are scarce.

In the current study, it was hypothesized that the application of Azotobacter chroococcum would reduce the need for mineral $\mathrm{N}$ fertilizer, and would uplift the productivity of dual-purpose triticale production system, in comparison to grain-only system under the Egyptian farming conditions. The objective of this study was to evaluate the performance of triticale grown in dual-purpose and grain-only production systems under variable rates of mineral $\mathrm{N}$ application, accompanied with Azotobacter chroococcum seed inoculation.

\section{Materials and methods}

\section{Site description}

A 2-year field trial (2018/2019 and 2019/2020) was conducted at the experimental station of the Faculty of Agriculture, Alexandria University, located in Alexandria, Northern Egypt $\left(31^{\circ} 20^{\prime} \mathrm{N}, 30^{\circ} \mathrm{E}\right)$. The climate of the experimental location is arid, with negligible amount of total precipitation during both seasons. Average monthly atmospheric temperature during the two respective seasons was $15.47^{\circ} \mathrm{C}$ and $16.79^{\circ} \mathrm{C}$. The soil type of the experimental site was sandy loam (500 $\mathrm{g} \mathrm{kg}^{-1}$ sand, $300 \mathrm{~g} \mathrm{~kg}^{-1}$ silt, and $200 \mathrm{~g} \mathrm{~kg}^{-1}$ clay), with $\mathrm{pH}$ of 8.1 and electrical conductivity of 1.3 $\mathrm{dS} \mathrm{m}{ }^{-1}$. The top $25 \mathrm{~cm}$ of the soil contained $1.60 \%$ organic matter, 100,30 , and 350 ppm available N, P, and K, respectively.

\section{Azotobacter isolation and molecular characterization}

Azotobacter isolation and molecular characterization, as well as inoculum preparation were done at the Microbiology Laboratory, Soil and Water Science Department, Faculty of Agriculture, Alexandria University, Alexandria, Egypt. Azotobacter was isolated from wheat crop rhizosphere soil samples by serial dilution method using nitrogen-free Jensen agar medium (Jensen, 1951). The isolate was maintained in nutrient broth with $50 \%$ glycerol at $-80^{\circ} \mathrm{C}$. Biochemical characterization of the isolates was carried out using the standard methods (Collee and Miles, 1989; Brenner et al., 2005). Specific eubacterial 16S rRNA primers 16Sa-F (5' -CGCTGGCGGCAGGCTTAACA-3') and 16Sb-R (5' CCAGCCGCAGGTTCCCCT-3') were used with genomic DNA of the strain using PCR protocols described by van Berkum and Fuhrmann (2000). A Perkin-Elmer 377 DNA sequencer, in combination with Dye Deoxy Terminator Cycle Sequencing Kit (Perkin-Elmer, Foster City, CA, N USA) was used for sequencing the purified PCR products. Sequence similarity BLAST searches were performed to compare the 16S rRNA sequence with other known related sequences using the nucleotide blast program (available at: http://blast.ncbi.nlm.nih.gov/ Blast.cgi). The sequence of the Azotobacter chroococcum isolate was registered at the Genbank with accession number MT474031. The final inoculum densities were adjusted to an absorbance at 530 $\mathrm{nm}$ which was equivalent to approximately $7 \times 10^{6} \mathrm{cfu} \mathrm{mL}^{-1}$. Twenty $\mathrm{ml}$ of bacterial suspension were used for the inoculation of $40 \mathrm{~g}$ seed, which was equivalent to a total of 0.51 suspension per $\mathrm{kg}$ seeds.

\section{Design and treatments}

The influence of five fertilizer treatments, on forage and grain yields of triticale in grain-only and dual-purpose systems (one for- 
age cut at stem elongation phase - GS31) was investigated. The experiment was laid out in a split plot design with three field replications. The main plots were assigned to the five tested fertilizer treatments, i.e., F1: only Azotobacter chroococcum (AC), F2: 25\% mineral $\mathrm{N}+\mathrm{AC}, \mathrm{F} 3: 50 \%$ mineral $\mathrm{N}+\mathrm{AC}, \mathrm{F} 4: 75 \%$ mineral $\mathrm{N}+$ $\mathrm{AC}$, and $\mathrm{F} 5: 100 \%$ mineral $\mathrm{N}$ without $\mathrm{AC}$. The two production systems, i.e., grain-only, and dual-purpose, were tested in the subplots. Each subplot was $2.4 \mathrm{~m}$ by $3 \mathrm{~m}\left(7.2 \mathrm{~m}^{2}\right)$. Mineral nitrogen, thereafter referred to as $\mathrm{mN}$, was applied in the form of ammonium nitrate $\left(\mathrm{NH}_{4} \mathrm{NO}_{3}, 33.5 \% \mathrm{~N}\right)$ and the different rates under investigation were calculated based on the recommended $\mathrm{N}$ fertilization for triticale in the region, amounting to $140 \mathrm{~kg} \mathrm{~N} \mathrm{ha}^{-1}$, and was split into 3 equal doses. First $\mathrm{mN}$ dose was applied to the plots 14 days after sowing and two more doses were applied at 30-day interval, as top dressing. Triticale grains were coated with AC inoculum directly before sowing, Arabic gum was added to insure complete adhesion. After inoculation, grains were left for 30 minutes to dry in the shade and then sown and covered with a thin soil layer to avoid exposure of the inoculum to the sun. To prevent cross-contamination of uninoculated grains, they were sown before the inoculated grains.

\section{Agricultural practices}

Seedbed was prepared by chisel plowing (to a depth of 20-25 $\mathrm{cm}$ ), followed by land levelling and ridging. Land was divided into experimental plots, and one plot was left without planting to separate between each two successive main plots assigned to the fertilizer treatments. Triticale was planted on $10^{\text {th }}$ and $1^{\text {st }}$ of November, during seasons 1 and 2, respectively. Seeds were drilled on the upper third part of both sides of the ridge with the recommended seeding rate of $96 \mathrm{~kg} \mathrm{ha}^{-1}$. An amount of $150 \mathrm{~kg} \mathrm{ha}^{-1}$ calcium mono-phosphate $\left(15.5 \% \quad \mathrm{P}_{2} \mathrm{O}_{5}\right)$ was added with seedbed preparation. All plots received equal amounts of irrigation on equal intervals, that began with sowing and stopped 20 days before grain harvesting. Selective herbicides were sprayed against broadleaf weeds.

\section{Measurements}

In the dual-purpose system, plants were cuts at early jointing (stem elongation) phase (GS31) according to Zadoks scale (Zadoks et al., 1974) to minimize the grain loss thereafter. At the time of cutting, plots were cut with a sickle $10 \mathrm{~cm}$ above ground surface and forage yield was immediately weighed in the field. A sample of approximately $1 \mathrm{~kg}$ from each plot was oven dried at $60^{\circ} \mathrm{C}$ for $48 \mathrm{~h}$, and dry matter content (DM) was determined. To determine the variations in fodder quality as affected by the fertilizer treatments, dried samples were ground to pass through a $1 \mathrm{~mm}$ sieve, then forage crude protein (CP) was determined as $\mathrm{N}$ content multiplied by 6.25 . Nitrogen was analysed using Kjeldahl apparatus, according to the Association of Official Analytical Chemists
(AOAC 2012). Fibre fractions were determined sequentially after Van Soest et al. (1991), as neutral detergent fibre (NDF), acid detergent fibre (ADF), and acid detergent lignin (ADF) using the semiautomatic ANKOM ${ }^{200}$ fibre analyser (ANKOM, model A200, New York, USA) using two filter bags for each sample (F57ANKOM Technology Corporation, Macedon, New York, USA). All analytical measurements were calculated as an average of two laboratory replications for each field sample.

In the grain-only system, plots were harvested at grain maturity after around 165 days after sowing; while, the dual-purpose plots were harvested few days later. At harvesting, plants in the two middle rows in each plot were cut with a sickle, directly above ground level. Biological yield (grain + straw) was weighed in the field, and then threshed using a stable threshing machine. After threshing and winnowing, the grain yield per plot was determined. Harvest index was calculated as grain yield $\left(\mathrm{kg} \mathrm{ha}^{-1}\right)$ divided by biological yield $\left(\mathrm{kg} \mathrm{ha}^{-1}\right)$ and expressed as percentage. Plant height $(\mathrm{cm})$ and spike length $(\mathrm{cm})$ were calculated as an average of five random plants from the middle ridges of each plot. The 100-grain weight $(\mathrm{g})$ was determined as an average of three random grain samples per plot. In the middle of each plot, fertile spikes were counted in one $\mathrm{m}^{2}$. Grain crude protein content was determined following the Kjeldahl method.

\section{Statistics}

Analysis of variance (ANOVA) of the data was done using PROC GLM of SAS ${ }^{\circledR}$ software 9.4 (SAS Institute Inc., 2012), after determining the appropriate error terms. Forage yield and quality data (D), in the dual-purpose system, were analysed using the following statistical model:

$D_{i j}=\mu+R_{i}+F_{j}+e_{i j}$

where: $\mu$ is the overall mean, $\mathrm{R}_{i}$ is the replication $(i=1,2,3), \mathrm{F}_{j}$ is the fertilizer treatment effect $(j=1,2,3,4,5), \mathrm{e}_{i j}$ is the experimental error.

In both production systems, final biological and grain yields and agronomic characteristics data (D), were analysed using the following statistical model:

$D_{i j k}=\mu+R_{i}+F_{j}+e_{i j}+P S_{k}+(F \times P S)_{j k}+e_{i j k}$

where: $\mu$ is the overall mean, $\mathrm{R}_{i}$ is the replication $(i=1,2,3), \mathrm{F}_{j}$ is the fertilizer treatment effect $(j=1,2,3,4,5), \mathrm{e}_{i j}$ is the experimental error ' $a$ ', $\mathrm{PS}_{k}$ is the production system effect $(k=1,2),(\mathrm{F} \times \mathrm{PS})_{j k}$ is the effect of the interaction between the fertilizer treatment and the production system, and $\mathrm{e}_{i j k}$ is the experimental error ' $b$ '.

ANOVA was run including the 'Year' effect, upon which Hartley test was performed (Hartley, 1951), which revealed homogeneity of variance's error between two years, only in case of quality parameters, i.e., $\mathrm{CP}$ and fibre fractions. Consequently, results of these parameters will be presented and discussed in a combined

Table 1. Variations in forage yield $\left(\mathrm{t} \mathrm{ha}^{-1}\right)$, dry matter, neutral detergent fibre, acid detergent fibre, acid detergent lignin, and forage crude protein contents $\left(\mathrm{g} \mathrm{kg}^{-1}\right)$, caused by the fertilizer treatment effect.

\begin{tabular}{lccccccc} 
Fertiliver treatment & \multicolumn{2}{c}{ Yield $^{2}$} & DM & NDF & ADF & ADL \\
& Season 1 & Season 2 & & & & \\
F1 & $3.2^{\mathrm{c}}$ & $4.2^{\mathrm{b}}$ & $122.35^{\mathrm{b}}$ & $508.50^{\mathrm{a}}$ & $266.97^{\mathrm{a}}$ & $19.83^{\mathrm{a}}$ & $92.03^{\mathrm{d}}$ \\
F2 & $5.19^{\mathrm{b}}$ & $5.42^{\mathrm{b}}$ & $123.64^{\mathrm{b}}$ & $513.97^{\mathrm{a}}$ & $265.58^{\mathrm{a}}$ & $19.23^{\mathrm{a}}$ & $103.85^{\mathrm{c}}$ \\
\hline F3 & $6.91^{\mathrm{ab}}$ & $7.55^{\mathrm{a}}$ & $137.65^{\mathrm{a}}$ & $525.93^{\mathrm{a}}$ & $266.63^{\mathrm{a}}$ & $20.58^{\mathrm{a}}$ & $125.57^{\mathrm{b}}$ \\
F4 & $7.32^{\mathrm{a}}$ & $8.62^{\mathrm{a}}$ & $137.02^{\mathrm{a}}$ & $513.45^{\mathrm{a}}$ & $260.17^{\mathrm{a}}$ & $21.24^{\mathrm{a}}$ & $133.77^{\mathrm{ab}}$ \\
\hline F5 & $7.21^{\mathrm{a}}$ & $8.41^{\mathrm{a}}$ & $138.74^{\mathrm{a}}$ & $523.20^{\mathrm{a}}$ & $268.76^{\mathrm{a}}$ & $22.73^{\mathrm{a}}$ & $136.68^{\mathrm{a}}$ \\
\hline
\end{tabular}

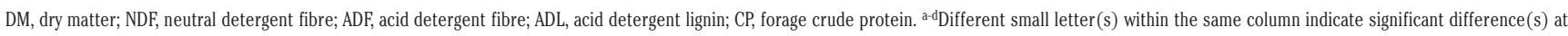
$\mathrm{P} \leq 0.05$. F1 (Only AC), F2 (25\% mN + AC), F3 $(50 \% \mathrm{mN}+\mathrm{AC}), \mathrm{F} 4(75 \% \mathrm{mN}+\mathrm{AC})$, F5 $(100 \% \mathrm{mN})$. 
analysis over the two growing seasons. On the other hand, forage yield of the dual-purpose system, and yield and agronomic characteristics of the grain-only system will be presented and discussed separately for each growing season, upon heterogeneity of variance's error. Prior to running the statistical analysis of the data, number of fertile spikes per $\mathrm{m}^{2}$, was subject to square root transformation, while harvest index was arcsine transformed and expressed as percentage. Means' comparisons were done using the Fisher's protected least significant difference (L.S.D.) procedure at $\mathrm{P} \leq 0.05$.

\section{Results}

\section{Forage yield and quality}

Statistical analysis revealed significant variations in the forage yield, DM and CP contents as affected by the five fertilizer treatments $(\mathrm{P} \leq 0.01)$, while fibre fractions (NDF, $\mathrm{ADF}$, and $\mathrm{ADL})$ were non-significantly different $(\mathrm{P} \geq 0.05)$. The amount of herbage yield was directly proportional to the $\mathrm{mN}$ component in the fertilizer treatments, with the highest significant herbage yield achieved when $50 \%, 75 \%$ or $100 \% \mathrm{mN}$ was applied, during both seasons (Table 1). On the other hand, the application of only AC led to the production of the lowest significant amount of herbage yield, during both seasons. The reduction in herbage yield from $100 \% \mathrm{mN}$ to the application of only AC reached 55.48, and $52.20 \%$ for seasons 1 and 2, respectively. Similarly, the highest significant DM content was achieved with application 100\% mN (138.74 $\left.\mathrm{g} \mathrm{kg}^{-1}\right)$, as well as 50 , and $75 \% \mathrm{mN}$ in combination with $\mathrm{AC}$ inoculation. The lowest DM accumulation was observed for AC inoculation alone $\left(122.35 \mathrm{~g} \mathrm{~kg}^{-1}\right)$. Moreover, the three tested fibre fractions showed non-significant response to the applied fertilizer treatment. They ranged from 508.50 to $525.93 \mathrm{~g} \mathrm{~kg}^{-1}$, from 260.17 to 268.76 $\mathrm{g} \mathrm{kg}^{-1}$, and from 19.23 to $22.73 \mathrm{~g} \mathrm{~kg}^{-1}$, for NDF, ADF, and ADL, respectively. The herbage $\mathrm{CP}$ content progressively increased with increasing the $\mathrm{mN}$ proportion in the fertilizer treatment, with highest significant CP content amounting to 136.68 and $133.77 \mathrm{~g} \mathrm{~kg}^{-1}$, for $100 \% \mathrm{mN}$ and $75 \% \mathrm{mN}+\mathrm{AC}$, respectively. The least significant $\mathrm{CP}$ content resulted from application of $\mathrm{AC}$ alone and was $92.03 \mathrm{~g} \mathrm{~kg}^{-1}$.

\section{Biological and grain yields and harvest index}

Statistical analysis revealed that the tested fertilizer treatments exerted significant influence on the biological $(\mathrm{P} \leq 0.05)$ and grain $(\mathrm{P} \leq 0.01)$ yields as well as the $\mathrm{HI}(\mathrm{P} \leq 0.01)$. Moreover, biological and grain yields were significantly variable as affected by the production system $(\mathrm{P} \leq 0.05)$. Nonetheless, the two-way interaction between fertilizer treatment and production system was significant only for biological yield ( $\mathrm{P} \leq 0.05)$.

The effects of fertilizer treatments on the biological and grain yields and HI are documented in Table 2. Similar to the forage parameters, maximum significant biological yield was obtained with the application of $\mathrm{mN}$ rates starting $50 \%$ and more during both seasons. Maximum amount of biological yield was 20.40, and $20.26 \mathrm{tha}^{-1}$, in seasons 1 and 2, respectively. The least amount of grain yield was produced with the application of AC alone (zero

Table 2. Variations in biological yield $\left(\mathrm{t} \mathrm{ha}^{-1}\right)$, grain yield $\left(\mathrm{t} \mathrm{ha}^{-1}\right)$ and harvest index $(\%)$ caused by the fertilizer treatment effect.

\begin{tabular}{|c|c|c|c|c|c|c|}
\hline \multirow[t]{2}{*}{ Fertilizer treatment } & \multicolumn{2}{|c|}{ Biological yield } & \multicolumn{2}{|c|}{ Grain yield } & \multicolumn{2}{|c|}{ HI } \\
\hline & Season 1 & Season 2 & Season 1 & Season 2 & Season 1 & Season 2 \\
\hline $\mathrm{F} 1$ & $14.29^{c}$ & $15.50^{\mathrm{b}}$ & $4.05^{b}$ & $4.53^{\mathrm{b}}$ & $28.28^{b}$ & $27.93^{b}$ \\
\hline $\mathrm{F} 2$ & $15.12^{\mathrm{bc}}$ & $15.94^{\mathrm{b}}$ & $4.81^{\mathrm{ab}}$ & $5.06^{\mathrm{ab}}$ & $28.72^{b}$ & $28.41^{\mathrm{b}}$ \\
\hline F3 & $19.59^{\mathrm{ab}}$ & $18.82^{\mathrm{ab}}$ & $5.95^{\mathrm{ab}}$ & $5.99^{a b}$ & $30.72^{\mathrm{ab}}$ & $29.97^{\mathrm{ab}}$ \\
\hline F4 & $19.72^{\mathrm{ab}}$ & $18.70^{\mathrm{ab}}$ & $6.78^{a}$ & $6.50^{\mathrm{a}}$ & $34.96^{\mathrm{a}}$ & $34.01^{\mathrm{a}}$ \\
\hline F5 & $20.40^{\mathrm{a}}$ & $20.26^{\mathrm{a}}$ & $6.62^{\mathrm{a}}$ & $6.89^{\mathrm{a}}$ & $35.34^{\mathrm{a}}$ & $34.86^{\mathrm{a}}$ \\
\hline
\end{tabular}

$\mathrm{HI}$, harvest index. ${ }^{\mathrm{a}-\mathrm{C} D i f f e r e n t ~ s m a l l ~ l e t t e r(s) ~ w i t h i n ~ t h e ~ s a m e ~ c o l u m n ~ i n d i c a t e ~ s i g n i f i c a n t ~ d i f f e r e n c e ~(s) ~ a t ~ P ~} \leq 0.05$. Fl (Only AC), F2 (25\% mN + AC), F3 (50\% mN + AC), F4 (75\% mN + AC), F5 (100\% mN).

Table 3. Variations in biological yield $\left(\mathrm{t} \mathrm{ha}^{-1}\right)$, grain yield $\left(\mathrm{t} \mathrm{ha}^{-1}\right)$, and harvest index (\%), caused by the production system effect.

\begin{tabular}{|c|c|c|c|c|c|c|}
\hline \multirow[t]{2}{*}{ Production system } & \multicolumn{2}{|c|}{ Biological yield } & \multicolumn{2}{|c|}{ Grain yield } & \multicolumn{2}{|c|}{ HI } \\
\hline & Season 1 & Season 2 & Season 1 & Season 2 & Season 1 & Season 2 \\
\hline Dual-purpose & $17.06^{\mathrm{b}}$ & $16.85^{b}$ & $4.98^{b}$ & $5.03^{b}$ & $30.00^{\mathrm{a}}$ & $29.11^{\mathrm{a}}$ \\
\hline Grain-only & $18.59^{\mathrm{a}}$ & $18.83^{\mathrm{a}}$ & $6.31^{\mathrm{a}}$ & $7.96^{\mathrm{a}}$ & $33.21^{\mathrm{a}}$ & $32.96^{\mathrm{a}}$ \\
\hline
\end{tabular}

HI, harvest index. a,bDifferent small letter(s) within the same column indicate significant differences at $\mathrm{P} \leq 0.05$.

Table 4. Variations in plant height $(\mathrm{cm})$, number of fertile spikes $\left(\mathrm{m}^{2}\right)$, spike length $(\mathrm{cm})$, and grain crude protein content $\left(\mathrm{g} \mathrm{kg}^{-1}\right)$, caused by the fertilizer treatment effect.

\begin{tabular}{|c|c|c|c|c|c|c|c|}
\hline \multirow{2}{*}{ Fertilizer treatment } & \multicolumn{2}{|c|}{ Plant height } & \multicolumn{2}{|c|}{ Number of fertile spikes } & \multicolumn{2}{|c|}{ Spike length } & \multirow[t]{2}{*}{ Grain CF } \\
\hline & Season 1 & Season 2 & Season 1 & Season 2 & Season 1 & Season 2 & \\
\hline $\mathrm{F} 1$ & $117.67^{\mathrm{c}}$ & $119.62^{\mathrm{c}}$ & $341.67^{c}$ & $345.26^{\mathrm{c}}$ & $15.72^{\mathrm{ab}}$ & $15.99 \mathrm{~b}$ & $169.38^{b}$ \\
\hline F2 & $121.33^{b c}$ & $120.36^{\mathrm{c}}$ & $383.33^{b}$ & $390.15^{b}$ & $15.17^{\mathrm{b}}$ & $16.07^{\mathrm{b}}$ & $179.02^{\mathrm{b}}$ \\
\hline F3 & $123.72^{\mathrm{bc}}$ & $125.95^{b}$ & $376.67^{\mathrm{bc}}$ & $389.94^{b}$ & $17.67^{\mathrm{a}}$ & $17.54^{\mathrm{a}}$ & $200.60^{\mathrm{a}}$ \\
\hline F4 & $130.00^{\mathrm{ab}}$ & $130.45^{\mathrm{ab}}$ & $398.33^{a b}$ & $396.45^{b}$ & $17.06^{\mathrm{ab}}$ & $17.64^{\mathrm{a}}$ & $204.40^{\mathrm{a}}$ \\
\hline F5 & $132.83^{\mathrm{a}}$ & $135.62^{\mathrm{a}}$ & $430.00^{\mathrm{a}}$ & $450.26^{\mathrm{a}}$ & $17.50^{\mathrm{a}}$ & $18.04^{\mathrm{a}}$ & $207.51^{\mathrm{a}}$ \\
\hline
\end{tabular}

CP, crude protein. ${ }^{\text {a-c }}$ Different small letter(s) within the same column indicate significant difference(s) at P $\leq 0.05$. F1 (Only AC), F2 (25\% mN + AC), F3 (50\% mN + AC), F4 (75\% mN + AC), F5 (100\% mN). 
$\mathrm{mN}$ ), and gradually increased with increasing the $\mathrm{mN}$ proportion in the fertilizer treatment. The consistent variations in biological and grain yields were reflected on the HI, which significantly increased with increasing the percentage of $\mathrm{mN}$, with maximum $\mathrm{HI}$ of 35.34 , and $34.86 \%$, in seasons 1 , and 2, respectively, against only 28.28 , and $27.93 \%$, for the two respective seasons, when only AC was applied.

Grain-only system was superior to dual-purpose system with regard to biological and grain yields in both seasons (Table 3), with a difference amounting to 1.53 , and $1.98 \mathrm{tha}^{-1}$ for biological yield, and 1.33 , and $1.93 \mathrm{t} \mathrm{ha}^{-1}$, for grain yield, during the two respective seasons. Nonetheless, HI was non-significantly variable between both production systems.

\section{Agronomic characteristics and grain protein content}

Statistical analysis for the effects of fertilizer treatments, production systems, and their interactions illustrated significant variations among plant height $(\mathrm{P} \leq 0.01)$, number of fertile spikes $(\mathrm{P} \leq 0.05)$, spike length $(\mathrm{P} \leq 0.05)$, and grain $\mathrm{CP}$ content $(\mathrm{P} \leq 0.05)$ as affected by the tested fertilizer treatments and production systems, while the interaction between the two studied factors was significant only in case of 100 -grain weight $(\mathrm{P} \leq 0.05)$.

Grain CP content ranged from 169.38 to $207.51 \mathrm{~g} \mathrm{~kg}^{-1}$, with non-significant difference between 50,75 , and $100 \% \mathrm{mN}$ applications (Table 4). Moreover, the tallest significant plants were reported for the application of $75 \% \mathrm{mN}+\mathrm{AC}$, as well as $100 \% \mathrm{mN}$ for the two seasons (Table 4). The application of $100 \% \mathrm{mN}$ during both seasons, in addition to $75 \% \mathrm{mN}+\mathrm{AC}$ in season 1 , resulted in the highest number of fertile spikes per $\mathrm{m}^{2}$. Little, however, significant variations in spike length were detected in response to the fertilizer treatments. In general, spike length ranged from 15.17 to $17.67 \mathrm{~cm}$ and from 15.99 to $18.04 \mathrm{~cm}$ during seasons 1 , and 2, respectively. The grain $\mathrm{CP}$ content was around $2 \%$ higher in case of dual-purpose system $\left(201.38 \mathrm{~g} \mathrm{~kg}^{-1}\right)$ than grain-only system (182.98 $\left.\mathrm{g} \mathrm{kg}^{-1}\right)$. Moreover, grain-only system was significantly superior to the dual-purpose system with regard to plant height, and spike length during both seasons. Noticeably, dual-purpose system gave significantly higher number of fertile spikes than grain-only system during both seasons (Table 5).

The interaction between fertilizer treatment and production system was significant only in case of biological yield and 100grain weight, during the two seasons. Table 6 revealed that, at low $\mathrm{mN}$ rates (zero and $25 \%$ ) grain-only system produced significantly higher biological yield than dual-purpose system, while increasing the $\mathrm{mN}$ rate in the fertilizer treatment (50 and $75 \%$ in addition to $\mathrm{AC}$, and $100 \%$ ) uplifted the biological yield of the dual-purpose system to become non-significantly different from that of the grain-only system. Similar effect was observed in case of $100-$ grain weight, during season 1 , where at $100 \% \mathrm{AC}$ and $25 \% \mathrm{mN}+$ $\mathrm{AC}$, grain-only system was superior to dual-purpose-system in 100 -grain weight, while at the higher rates of $\mathrm{mN}$, both production systems produced significantly similar 100-grain weight. During

Table 5. Variations in plant height $(\mathrm{cm})$, number of fertile spikes $\left(\mathrm{m}^{2}\right)$, spike length $(\mathrm{cm})$, and grain crude protein content $\left(\mathrm{g} \mathrm{kg}^{-1}\right)$, caused by the production system effect.

\begin{tabular}{|c|c|c|c|c|c|c|c|}
\hline \multirow[t]{2}{*}{ Production system } & \multicolumn{2}{|c|}{ Plant height } & \multicolumn{2}{|c|}{ Number of fertile spikes } & \multicolumn{2}{|c|}{ Spike length } & \multirow[t]{2}{*}{ Grain CP } \\
\hline & Season 1 & Season 2 & Season 1 & Season 1 & Season 1 & Season 2 & \\
\hline Dual-purpose & $118.29^{b}$ & $121.85^{b}$ & $414.67^{\mathrm{a}}$ & $201.38^{a}$ & $15.87^{\mathrm{b}}$ & $16.08^{b}$ & $201.38^{a}$ \\
\hline Grain-only & $131.93^{\mathrm{a}}$ & $130.95^{\mathrm{a}}$ & $357.33^{\mathrm{b}}$ & $182.98^{\mathrm{b}}$ & $17.38^{\mathrm{a}}$ & $18.03^{\mathrm{a}}$ & $182.98^{b}$ \\
\hline
\end{tabular}

$\mathrm{CP}$, crude protein. ${ }^{\mathrm{a}, \mathrm{b}}$ Different small letter $(\mathrm{s})$ within the same column indicate significant differences at $\mathrm{P} \leq 0.05$.

Table 6. Variations in the biological yield $\left(\mathrm{t} \mathrm{ha}^{-1}\right)$, and 100-grain weight $(\mathrm{g})$, caused by the fertilizer treatment $\times$ production system effect.

\begin{tabular}{|c|c|c|c|c|}
\hline \multirow{3}{*}{ Fertilizer treatment } & \multicolumn{3}{|c|}{ Biological yield } & \\
\hline & & & \multicolumn{2}{|c|}{ Season 2} \\
\hline & Dual-purpose & Grain-only & Dual-purpose & Grain-only \\
\hline $\mathrm{F} 1$ & $12.56^{\mathrm{bB}}$ & $16.02^{\mathrm{bA}}$ & $13.95^{\mathrm{bB}}$ & $17.04^{\mathrm{bA}}$ \\
\hline F2 & $13.37^{\mathrm{bB}}$ & $16.87^{\mathrm{bA}}$ & $14.25^{\mathrm{bB}}$ & $17.62^{\mathrm{bA}}$ \\
\hline F3 & $18.89^{\mathrm{aA}}$ & $20.28^{\mathrm{aA}}$ & $17.96^{\mathrm{aA}}$ & $19.68^{\mathrm{aA}}$ \\
\hline F4 & $19.56^{\mathrm{aA}}$ & $19.89^{\mathrm{aA}}$ & $18.04^{\mathrm{aA}}$ & $19.36^{\mathrm{aA}}$ \\
\hline F5 & $20.92^{\mathrm{aA}}$ & $19.88^{\mathrm{aA}}$ & $20.06^{\mathrm{aA}}$ & $20.45^{\mathrm{aA}}$ \\
\hline \multirow{3}{*}{ Fertilizer treatment } & \multicolumn{3}{|c|}{100 -grain weight } & \\
\hline & \multicolumn{2}{|c|}{ Season 1} & \multicolumn{2}{|c|}{ Season 2} \\
\hline & Dual-purpose & Grain-only & Dual-purpose & Grain-only \\
\hline $\mathrm{F} 1$ & $2.58^{\mathrm{bB}}$ & $2.87^{\mathrm{bA}}$ & $2.66^{\mathrm{bA}}$ & $2.73^{\mathrm{bA}}$ \\
\hline $\mathrm{F} 2$ & $2.64^{\mathrm{bB}}$ & $2.80^{\mathrm{bA}}$ & $2.64^{\mathrm{bA}}$ & $2.79^{\mathrm{bA}}$ \\
\hline F3 & $2.72^{\mathrm{abA}}$ & $2.80^{\mathrm{bA}}$ & $2.78^{\mathrm{abA}}$ & $2.86^{\mathrm{abA}}$ \\
\hline F4 & $2.70^{\mathrm{abA}}$ & $2.72^{\mathrm{bA}}$ & $2.75^{\mathrm{abA}}$ & $2.93^{\mathrm{abA}}$ \\
\hline $\mathrm{F} 5$ & $2.86^{\mathrm{aA}}$ & $3.00^{\mathrm{aA}}$ & $2.94^{\mathrm{aA}}$ & $3.04^{\mathrm{aA}}$ \\
\hline
\end{tabular}

a,bifferent small letter(s) within the same column, and/or A,Bdifferent capital letter(s) within the same row for each growing season of the same parameter, indicate significant differences at P $\leq 0.05$. Fl (Only AC), F2 $(25 \% \mathrm{mN}+\mathrm{AC}), \mathrm{F} 3(50 \% \mathrm{mN}+\mathrm{AC}), \mathrm{F} 4(75 \% \mathrm{mN}+\mathrm{AC}), \mathrm{F} 5(100 \% \mathrm{mN})$. 
season 2, both systems produced similar 100-grain weight across all fertilizer treatments.

\section{Discussion}

\section{Fertilization management}

In the current study, all parameters were positively responsive to higher levels of $\mathrm{mN}$, where the application of $100 \% \mathrm{mN}$ resulted in the highest forage and grain yields and yield components in the dual-purpose, as well as the grain-only production systems. Similar observations were reported by Bilal et al. (2017) for dual purpose oat. The positive response to increasing $\mathrm{mN}$ levels was attributed to the production of leafier plants with increased chlorophyll content, which enhanced the photosynthetic activity of the canopy and encouraged the cell division and elongation, that was positively reflected on the yield. Unlike other cereals, triticale is advantaged by its ability to continuously accumulate more nitrogen, during heading and late developmental stages, moreover, roots of triticale continue to grow after flowering and are subject to late degeneration, permitting high $\mathrm{N}$ absorption till late stages of maturity (Alaru et al., 2009). In addition, the higher number of fertile spikes and higher spike length at high $\mathrm{N}$ rates, significantly contributed to the increase in grain yield of both dual-purpose and grain-only triticale with increased $\mathrm{N}$ rates. Nonetheless, Evert and Honermeier (1999) reported that increasing N fertilization significantly increased number of spikelets on triticale main stem and tillers at anthesis. They attributed this to the continuation of spikelet formation at end of rapid rate of spikelet initiation with high $\mathrm{N}$ fertilizer rates, while insufficient $\mathrm{N}$ rates cause spikelet abortion. Obviously, the response of the HI to the fertilization treatments, was consistent with the response of the biological and grain yields, from which the HI was calculated, i.e., fertilization treatments which led to increasing the biological and grain yields, consequently increased the HI. These results were in agreement with the findings of Alaru et al. (2009).

In addition to the role of the nitrogen in amino acids synthesis (the protein precursor), $\mathrm{N}$ fertilization is known to enhance the vegetative growth, thus, increases the leaf to stem ratio of the canopy. Increasing $\mathrm{N}$ fertilization, therefore, resulted in significant increases in forage $\mathrm{CP}$ content, as the leaf component contains higher CP concentration than the stem component (Bilal et al., 2017). Controversial effects of increased $N$ supply on forage fibre fractions were reported in previous studies. While Bilal et al. (2017) reported a general increase in the crude fibre content with increasing $\mathrm{N}$ fertilization, Obour et al. (2018) documented a decrease in NDF and ADF and stability of ADL. In the current study, however, the three fibre fractions (NDF, ADF, ADL) were non-significantly variable among the tested fertilizer treatments. Similar results were reported by BenYoussef et al., (2019) for triticale grown in Tunisia.

Despite the fact that $100 \% \mathrm{mN}$ rate resulted in highest significant forage and grain yields, this dose is no more recommended, due to the high risk of lodging and pre-harvest sprouting (Alaru et al., 2009), as well as, the hazardous effects on the environment usually accompanying the high $\mathrm{mN}$ doses. Aim of the current study, therefore, was to point out affordable, and safe alternatives that would allow for reducing the used amounts of $\mathrm{mN}$. When triticale seeds where inoculated with AC prior to sowing, lower levels of $\mathrm{mN}$ fertilizer were sufficient to reach as much yield as with the application of $100 \% \mathrm{mN}$ doses, without AC inoculation. Significantly high amounts of forage and grain yields were achieved from both planting systems when $\mathrm{mN}$ fertilization was reduced to $50 \%$ of the recommended, accompanied with $\mathrm{AC}$ inoculation. Similar results were reported by Patel et al. (2018) for sorghum. The success of AC inoculation in uplifting the forage and grain yields at reduced $\mathrm{mN}$ rates, might be attributed to its numerous positive effects on the crop growth and soil health. The AC improves plant growth and productivity through the biosynthesis of growth promoting hormones, stimulation of rhizosphere microbial community and producing phytopathogenic inhibitors. In addition, AC contributes to the formation of lateral roots, thus, increasing the root surface area, resulting in better water and nutrients uptake (Jnawali et al., 2015). Nonetheless, it is evident that microbial inoculants improve the soil fertility, by increasing the amount and availability of the soil nutrients, and boosting the biological fixation of atmosphere nitrogen, up to $20 \mathrm{~kg} \mathrm{~N} \mathrm{ha}^{-1}$ per year (Kizilkaya, 2009). Moreover, from the economic point of view, the cost of the $100 \% \mathrm{mN}$ application $\mathrm{ha}^{-1}\left(140 \mathrm{~kg} \mathrm{~N} \mathrm{ha}^{-1}\right)$, when supplied in the form of ammonium nitrate fertilizer, was around 95.80 US\$, while only 6.37 US\$ were required for AC seed inoculation $\mathrm{ha}^{-1}$ (values collected from the local market). Thus, replacing $50 \%$ of the $\mathrm{mN}$ with $\mathrm{AC}$ seed inoculation would save 41.53 US\$ (around $43 \%$ ) of the fertilization costs, thus, prove economic for the farmer.

\section{Production system}

Cutting winter-sown cereals is a potential source of good amount of forage of reasonable quality that would fill a feed gap in many areas. However, accurate decision should be made about the stage of maturity at which the crop should be cut, in order to achieve reasonable amount of forage yield with satisfactory nutritive value on the one hand, and reduce subsequent losses in grain yield, on the other hand (Salama, 2019). This decision should be made based on the stage of apical development which is variable among different crop species (Baron et al., 2015). Results of previous investigations showed that, in case of dual-purpose cereals, forage removal at early jointing is highly recommended (Baron et al., 2015; Rajae et al., 2017). Cereal crops at early jointing, prior to boot stage, consist mostly of leaves (around 80\%), with high CP content, in addition, all plant parts, including the stems, are highly digestible (Cherney and Marten, 1982). In similar Mediterranean contexts, early jointing was approved as the optimum developmental stage at which cereal crops should be cut in a dual-purpose system (Sadreddine, 2016; Rajae et al., 2017; Salama, 2019). Therefore, dual-purpose triticale in the current study was cut at early jointing stage; i.e., GS31 according to Zadoks scale (Zadoks et al., 1974).

In the current study, around $7.23 \mathrm{tha}^{-1}$ forage yield could be achieved when dual-purpose triticale was cut at early jointing phase. This was accompanied with a reduction in final grain yield of around 16 and $22 \%$ during seasons 1 and 2, respectively, compared to the grain-only system. A similar amount of reduction in grain yield (22\%) was reported by Sadreddine (2016) for dual-purpose triticale grown in Tunisia. Observably, cutting dual-purpose triticale at GS31 enhanced the production of fertile spikes, compared to grain-only system. This was probably attributed to the removal of apical dominance, which encouraged the production of more new fertile tillers upon cutting (Briske and Richards, 1994). Nonetheless, forage removal early in the season would extend the tillering period which would result in more tillers bearing more fertile spikes (Bonachela et al., 1995). On the other hand, forage removal in the dual-purpose system resulted in significantly shorter plants than in the grain-only system, this was true for several dual-purpose cereals like triticale, oat and barley, and was believed to be useful in reducing the risk of lodging (Droushiotis, 1984). The 100-grain weight is another important yield component, grain- 
only system gave significantly heavier grains than the dual-purpose system only when zero and $25 \% \mathrm{mN}$ was used, while the application of $100 \% \mathrm{mN}$ uplifted the 100 -grain weight of the dualpurpose system, which was at par with the application of 50 or $75 \% \mathrm{mN}$ in addition to $\mathrm{AC}$ seed inoculation. The decrease in the 100 -grain weight after cutting, at low $\mathrm{mN}$ rates, was probably because considerable amount of carbohydrates and stored nutrients were directed to the regrowth generation after cutting rather than grain filling. On the other hand, at higher $\mathrm{mN}$ rates in presence of AC more nutrients were available to support both regeneration and grain filling. Comparable 1000-grain weight was reported by Sadreddine (2016) for both production systems when the recommended rate of $108 \mathrm{~kg} \mathrm{~N} \mathrm{ha}^{-1}$ was applied along the growing season.

Despite the variations in biological and grain yields between both production systems, they resulted in significantly similar HI, which means that forage cutting in the dual-purpose system nonsignificantly affected the ability of the plant to convert the photosynthetic assimilates into the economic component, i.e., grain yield. This might be a consequence of the breeding efforts made to improve the translocation of assimilates and, thus, grain yield of dual-purpose triticale genotypes (Royo, 1999). Obviously, the significantly shorter spikes produced after forage cutting, carried a smaller number of grains per spike, which was probably the reason behind the reduction in grain yield in the dual-purpose system (Sadreddine, 2016).

A significant increase in grain protein content was detected after forage cutting, which was negatively correlated to the grain yield, however, positively correlated to the number of fertile spikes. This might be attributed to the abundant soil fertility that allows the plant to absorb more nitrogen, especially after cutting at GS31, that would substitute the nitrogen lost with forage cutting (Royo et al., 1994). In addition, the active translocation of nitrogen from the leaves and other plant parts to the grains, after cutting, might also contribute to the higher grain protein in the dual-purpose triticale (Francia et al., 2006). Similar results were reported for dual-purpose barley, oat and triticale (Francia et al., 2006; Sadreddine, 2016).

In managing the small-grain cereals for dual-purpose cropping, agronomic aspects, as well as economic incentives should be taken into account (Royo et al., 1997; Salama, 2019). Economic analysis of both production systems, guided with the market prices for triticale grain and forage yields, revealed that the loss in grain income due to forage cutting amounted to $379.28 \mathrm{US} \mathrm{ha}^{-1}$ (resulting from $2.13 \mathrm{t} \mathrm{ha}^{-1}$ reduction in grain yield in average for both seasons), while the gain in forage income amounted to $465.01 \mathrm{US} \$ \mathrm{ha}^{-1}$ (resulting from $7.23 \mathrm{t} \mathrm{ha}^{-1}$ forage yield in average for both seasons). Hence, the extra income resulting from triticale forage cutting was sufficient to compensate the grain yield reduction in the dual-purpose production system, confirming the profitability of the system.

\section{Conclusions}

The experimental approach used in the current study highlighted significant opportunity for the strategic use of triticale for forage and grain production under irrigated conditions of the Mediterranean region. Current results present a compelling case for the wider potential of dual-purpose triticale to increase farm productivity and profitability across Egypt's intensive farming system. Around $7.23 \mathrm{t} \mathrm{ha}^{-1}$ forage yield was obtained without drastically sacrificing grain yield (19\% reduction in average), resulting in a significant increase in the net income of the dual-purpose pro- duction system, due to the good prices of triticale green forage in the region. Inoculation of triticale seeds with $\mathrm{AC}$ allowed for the reduction of the used amount of mineral nitrogen to $50 \%$, accompanied with $43 \%$ decrease in the fertilization costs, without any decrease in the forage and grain yields. Thus, in similar conditions to the current study, it is recommended to expand the production of dual-purpose triticale in the winter season, while reducing $\mathrm{mN}$ fertilizer rate to $50 \%$ in combination with $\mathrm{AC}$ seed inoculation.

\section{References}

Aazadi MS, Siyadat SA, Syahbidi MMP, Younesi E, 2014. The study effect of nitrogen, Azotobacter Spp. and Azospirillum Spp. on phenological and morphological traits of durum wheat cultivars in Dehloran Region, Iran. Cercetari Agronom. Moldova 47:15-21.

Alaru M, Laur Ü, Eremeev V, Reintam E, Selge A, Noormets M, 2009. Winter triticale yield formation and quality affected by $\mathrm{N}$ rate, timing and splitting. Agric. Food Sci. 18:76-90.

AOAC, 2012. International official methods of analysis (19 th Ed.). Association of Official Analytical Chemists, Gaithersburg, MD, USA.

Ayalew H, Kumssa TT, Butler TJ, Ma XF, 2018. Triticale improvement for forage and cover crop uses in the Southern Great Plains of the United States. Front. Plant Sci. 9:1130.

Baron VS, Juskiw PE, Aljarrah M, 2015. Triticale as a forage. In: Triticale. Springer, Cham., pp. 189-212.

Bell LW, Harrison MT, Kirkegaard JA, 2015. Dual-purpose cropping-capitalising on potential grain crop grazing to enhance mixed-farming profitability. Crop Pasture Sci. 66:i-iv.

BenYoussef S, Kachout SS, Abidi S, Saddem B, Ismail J, Salem BH, 2019. Effect of different levels of nitrogen fertilization on forage yields and quality of hairy vetch (Vicia villosa, Roth) triticale (X Tritcosecale, Wittmack) mixtures. Open Agric. J. 13(1).

Bilal M, Ayub M, Tariq M, Tahir M, Nadeem MA, 2017. Dry matter yield and forage quality traits of oat (Avena sativa L.) under integrative use of microbial and synthetic source of nitrogen. J. Saudi Soc. Agric. Sci. 16:236-41.

Bilgili U, Cifci EA, Hanoglu H, Yagdi K, Acikgoz E, 2009. Yield and quality of triticale forage. J Food Agric. Environ. 7:55660.

Blum A, 2014. The abiotic stress response and adaptation of triticale - A review. Cereal Res. Commun. 42:359-75.

Bonachela S, Orgaz F, Fereres E, 1995. Winter cereals grown for grain and for the dual purpose of forage plus grain I. Production. Field Crops Res. 44:1-11.

Brenner DJ, Krieg NR, Staley JT, 2005. Bergeys manual of systematic bacteriology. volume two: The Proteobacteria. Part B: the Gammaproteobacteria (Second Ed. Vol. 2): Library of Congress Cataloguing-in-Publication Data.

Briske DD, Richards JH, 1994. Physiological responses of individual plants to grazing: current status and ecological significance. pp 147-176 in Ecological implications of livestock herbivory in the west. Society for Range Management, Denver, Colorado, USA.

Cherney JH, Marten GC, 1982. Small grain crop forage potential: II. Interrelationships among biological, chemical, morphological, and anatomical determinants of quality 1. Crop Science 22:240-5.

Collee JG, Miles PS, 1989. Tests for identification of bacteria. In: Collee JG, Duguid JP, Fraser AG, Marmion BP (Eds.), Practical medical microbiology. Churchil Livingstone, NY, 
USA, pp 141-160.

Droushiotis DN, 1984. The effect of variety and harvesting stage on forage production of barley in a low-rainfall environment. J. Agric. Sci. 102:289-93.

Evert F, Honermeier B, 1999. Spikelet initiation of winter triticale and winter wheat in response to nitrogen fertilization. Eur. J. Agron. 11:107-13.

FAOSTAT, 2018. Statistical yearbook. Food and Agriculture Organization of the United Nations, Rome, Italy.

Francia E, Pecchioni N, Nicosia OLD, Paoletta G, Taibi L, Franco V, Delogu G, 2006. Dual-purpose barley and oat in a Mediterranean environment. Field Crops Res. 99:158-66.

Giunta F, Motzo R, Fois G, Bacciu P, 2015. Developmental ideotype in the context of the dual $\square$ purpose use of triticale, barley and durum wheat. Annals Appl. Biol. 166:118-28.

Habiba HE, Salama HS, Bondok AT, 2018. Effect of the integrated use of mineral-and bio-fertilizers on yield and some agronomic characteristics of fodder pearl Millet (Pennisetum glaucum L.). Alexandria Sci. Exchan. J. 39:282-95.

Hajighasemi S, Keshavarz-Afshar R, Chaichi MR, 2016. Nitrogen fertilizer and seeding rate influence on grain and forage yield of dual-purpose barley. Agron. J. 108:1486-94.

Hartley HO, 1950. The maximum F-ratio as a short-cut test for heterogeneity of variance. Biometrika 37:308-12.

Jensen HL, 1951. Notes on the biology of Azotobacter. In Proceedings of the Society for Applied Bacteriology. Blackwell Publishing Ltd., Oxford, UK, 14(1):89-94.

Jnawali AD, Ojha RB, Marahatta S, 2015. Role of Azotobacter in soil fertility and sustainability - A Review. Adv. Plant Agric. Res. 2:1-5.

Kizilkaya R, 2009. Nitrogen fixation capacity of Azotobacter spp. strains isolated from soils in different ecosystems and relationship between them and the microbiological properties of soils. J. Environ. Biol. 30:73-82.

Liu W, Maurer HP, Leiser WL, Tucker MR, Weissmann S, Hahn V, Würschum T, 2017. Potential for marker-assisted simultaneous improvement of grain and biomass yield in triticale. Bioener. Res. 10:449-55.

Obour A, Holman JD, Schlegel A, 2018. Seeding rate and nitrogen application effects on spring oat and triticale forage. Kansas Agric. Exp. Station Res. Rep. 4:5.

Quatrin MP, Olivo CJ, Simonetti GD, Bratz VF, Godoy GLD, Casagrande LG, 2019. Response of dual-purpose wheat to nitrogen fertilization and seed inoculation with Azospirillum brasilense. Ciênc. Agrotecnol. 43:1-10
Royo C, 1999. Plant recovery and grain-yield formation in barley and triticale following forage removal at two cutting stages. J. Agron. Crop Sci. 182:175-83.

Royo C, Insa JA, Boujenna A, Ramos JM, Montesinos E, Garcia del Moral L, 1994. Yield and quality of spring triticale used for forage and grain as influenced by sowing date and cutting stage. Field Crop Res. 37:161-8.

Royo C, Lopez A, Serra J, Tribo F, 1997. Effect of sowing date and cutting stage on yield and quality of irrigated barley and triticale used for forage and grain. J. Agron. Crop Sci. 179:227-34.

Sadreddine B, 2016. Yield and quality of dual-purpose barley and triticale in a semi-arid environment in Tunisia. Afr. J. Agric. Res. 11:2730-5.

Salama HSA, 2019. Dual purpose barley production in the Mediterranean climate: effect of seeding rate and age at forage cutting. Int. J. Plant Prod. 13:285-95.

Salama HSA, Badry HH, 2020. Effect of partial substitution of bulk urea by nanoparticle urea fertilizer on productivity and nutritive value of teosinte varieties. Agron. Res [In press].

SAS Institute Inc., 2012. Statistical Analysis System (SAS), PC Windows Version 9.4 SAS Institute Inc., Cary, NC, USA.

Patel KM, Patel DM, Gelot DG, Patel IM, 2018. Effect of integrated nutrient management on green forage yield, quality and nutrient uptake of fodder sorghum (Sorghum bicolor L.). Int. J. Chem Stud. 6:173-6.

Rajae K, Fatima G, Chaouki AF, Mohammed I, 2017. Forage and grain production of dual-purpose triticale grown under Moroccan conditions. Int. J. Agric. Sci. Res. 7:401-10.

Van Berkum P, Fuhrmann JJ, 2000. Evolutionary relationships among the soybean bradyrhizobia reconstructed from $16 \mathrm{~S}$ rRNA gene and internally transcribed spacer region sequence divergence. Int. J. Syst. Evol. Microbiol. 50:2165-72.

Van Soest PV, Robertson JB, Lewis BA, 1991. Methods for dietary fibre, neutral detergent fibre, and nonstarch polysaccharides in relation to animal nutrition. J. Dairy Sci. 74:3583-97.

Wani SA, Chand S, Wani MA, Ramzan M, Hakeem KR, 2016. Azotobacter chroococcum - A potential biofertilizer in agriculture: an overview. In: Hakeem K, Akhtar J, Sabir M (Eds.) Soil science: agricultural and environmental prospectives. Springer, Cham.

Zadoks JC, Chang TT, Konzak CF, 1974. A decimal code for the growth stages of cereals. Weed Res. 14:415-21. 